\title{
De-awning of Agropyron spicatum cultivator for use as an understory grass on erosive sites
}

\author{
by Carl J. Goebel ${ }^{1}$ and Mohammed Tazi ${ }^{2}$
}

\begin{abstract}
South-facing, semi-arid slopes supporting sagebush (Artemisia tridentata) with scant understory are difficult sites for establishment of perennial vegetative cover in Central Washington. Bluebunch wheatgrass (Agropyron spicatum) is the most ubiquitous, widely distributed native perennial where exotic annuals are a competitive problem. It can be found as an understory associate or in open stands.

Secar is a cultivar, of A. spicatum developed in the Pacific Northwest. Unfortunately, the percent germination of secar seed has been found to be low. It was suspected that a possible inhibitor exists in the awn and mechanical removal may result in earlier and greater germinative ability for increased establishment on Conservation Reserve Program lands.

It was found that total germination was not significantly affected by temperature treatment but an apparent difference in rate was determined. A significant increase in germination occurred with awn removal. Specific location of an inhibitor(s) was not statistically apparent.
\end{abstract}

Key words: Agropyron spicatum, germination, seedling vigor, reseeding

\section{Introduction}

One of the important native grasses that often exists in shrub or tree communities of the Pacific Northwest Region is bluebunch wheatgrass (Agropyron spicatum) (Pursh) Scribn. and $\mathrm{Sm}$. This grass is the most ubiquitous native perennial found in the region. It can be abundantly found as an understory of sagebrush (Artemisia spp.), rabbitbrush (Chrysothamnus spp), bitterbrush (Purshia tridentata) and ponderosa pine (Pinus ponderosa). It is also abundant in open stands.

Because of the geographical extent of the species, many variations exist. A cultivar that has been developed by personnel of the USDA Plant Materials Center at Washington State University has been named "Secar" (Anonymous 1979). The perennial grass has the typical bunchgrass appearance with abundant leaves that are approximately 15 to $25 \mathrm{~cm}$ (6-11 in.) at maturity which are narrow and hairy on the top surface. It has numerous fine culms that are erect and green or blue-green in color. Spikelets are 1 to $2.5 \mathrm{~cm}$ long with small seeds that usually have divergent awns that are $1-2 \mathrm{~cm}$ long. The awn is resilient and has not been known to mechanically injure livestock.

"Secar", is drought-tolerant and persists under adverse conditions and has potential for use on Conservation Reserve

\footnotetext{
${ }^{1}$ Professor, Department of Natural Resource Sciences, Washington State University, Pullman, WA 99164-6410, U.S.A.

${ }^{2}$ Manager, Plant Materials Center, Service de l'Amenagement des Parcours, El Jadida, Morocco.
}

\section{Résumé}

Les pentes semi-arides, orientées vers le sud, couvertes d'armoise de l'ouest et possédant un sous-étage clairsemé constituent des sites difficiles pour ce qui est de l'établissement d'un couvert végétal vivace dans le centre de l'Etat de Washington. L'agropyron à chaume bleu (Agropyron spicatum) est la plante indigène vivace la plus largement distribuée un peu partout où les annuelles exotiques constituent un problème de compétition. On la retrouve associée dans le sous-étage ou dans des peuplements ouverts.

Le secar est un cultivar d'A. spicatum développé dans le nordouest du Pacifique. Malheureusement, le pourcentage de germination des semences de secar est faible. On suppose qu'un inhibiteur potentiel existe dans la barbe de la semence, et sa suppression pourrait résulter en une capacité plus grande et plus hâtive de germination destinée à une plus importante création de terres du Programme de réserve de conservation.

La germination totale n'a pas été significativement affectée par un traitement de température, mais une différence apparente dans la vitesse a été déterminée. Une augmentation significative de la germination est apparue suite à la suppression de la barbe. La localisation spécifique du ou des inhibiteurs n'était statistiquement apparente.

Mots clés: Agropyron spicatum, germination, vigueur du semis, semailles

Program sites. Although growth usually begins in spring after many annual weed species, "Secar" often renews growth in late summer and provides forage in the fall (Goebel 1978). The species is palatable for both domestic and wild animals. (Harris and Goebel, 1976).

A major disadvantage of using "Secar" in establishment of agroforestry ventures is its relatively low germinative ability. Although variable, dependent upon seed source and age, germination may average as low as 50 to $60 \%$ (Goebel et al. 1988). One of the reasons that germinative quality varies, could be the length of the awn or beard maintained on the seed. If an inhibitor is present in the awn then its removal may increase germination unless the seed is injured during the debearding process. If a germinative inhibitor is present in the awn it would be important to locate its position to determine whether the entire or a portion of the awn, must be removed to improve germinative ability.

\section{Methods}

Experiments were conducted during the summer of 1989 in germination chambers under controlled temperatures and light conditions. One-year-old seeds were donated by the Herrman Nursery located near Connell in southern Washington. Four, 14.5-cm diameter petri dishes covered with germination paper with 50 seeds per dish, kept moist each day, were placed in growth chambers per treatment.

Seeds were considered germinated when the seminal root emerged $1 \mathrm{~mm}$. Germination percentages were obtained by counting germinated seeds daily. Rate of germination was 
Table 1. Effect of variable and constant temperatures on germination percentage and vigor index of Secar bluebunch wheatgrass

\begin{tabular}{ccc}
\hline $\begin{array}{c}\text { Temperatures } \\
\left({ }^{\circ} \mathbf{C}\right)\end{array}$ & $\begin{array}{c}\text { Percent germination } \\
\text { (14th day) }\end{array}$ & Vigor index $^{\mathbf{2}}$ \\
\hline 5 & $51 a$ & $3.6 c$ \\
10 & $53 a$ & $3.8 c$ \\
15 & $53 a$ & $8.8 b$ \\
20 & $57 a$ & $9.8 b$ \\
$25-15$ & $56 a$ & $9.4 b$ \\
\hline
\end{tabular}

'Means followed by the same letter do not differ significantly from each other at the $5 \%$ of probability using Duncan's multiple range test.

${ }^{2}$ (Vigor Index) $V I=N X / D X$ where:

$N X=$ number of seeds germinated/day

$D X=$ number of days from start of germination to $X$ day (Maguire 1962).

determined by using the Vigor Index formula as described by Maguire (1962): VI=NX/DX: numbers of seeds germinated on $\mathrm{X}$ day and DX number of days from the beginning of the germination test to X-day.

Germination tests were conducted at $5,10,15$ and $20^{\circ} \mathrm{C}$. In addition, an alternating temperature $25-15^{\circ} \mathrm{C}(12$ hours each) was also used to simulate germinative conditions during the natural growing season. Light was provided on a continuous basis.

After optimal germination temperatures were determined, four trials of awned versus de-awned seeds were begun to determine whether germination would be affected by awn removal. All de-awning trials were run at the $20^{\circ} \mathrm{C}$ temperature since this appeared to be optimal for Secar germination.

To determine the potential location of an inhibitor or group of inhibitors within the awn of Secar seeds the tip or upper one-third of the awn was initially removed. In addition, onehalf, two-thirds and the complete awn were removed and germination trials were compared to seeds with their awns intact for two weeks.

\section{Results}

Initial seed trials indicated that total germination was not significantly affected by temperature treatments as indicated in Table 1. There were no significant differences at the .05 level between germination at all temperatures. Initial experiments were conducted with awns intact. Total germination ranged from 51 to $56 \%$ and averaged $54 \%$.

Speed of germination in seeds with awns was positively correlated with increase in temperature. Secar germination was delayed significantly at $5^{\circ} \mathrm{C}$ and $10^{\circ} \mathrm{C}$ (Table 1) compared with other temperature treatments. Speed of germination was most rapid at the $20^{\circ} \mathrm{C}$ and was significantly different from that of $5^{\circ}$ and $10^{\circ} \mathrm{C}$ temperatures. These results agree with those reported for other wheatgrasses by Ellern and Tadmore (1966). They characterized an ideal plant for establishment on semi-arid rangelands as one with the inherent ability to germinate and develop at low temperatures in order to survive a hot, dry climate. These current trials do not indicate that Secar is able to germinate at a wide range of temperatures corresponding to the temperatures typical during field conditions of spring, summer and fall in central Washington.

As indicated in Table 2 there was a significant increase in germination with total removal of the awn. Percent germination averaged $51.2 \%$ for awned bluebunch wheatgrass seeds and $80.0 \%$ for de-awned seeds. The increase of germination by de-awning could offset the cost of additional
Table 2. Germination of awned and totally de-awned "Secar" bluebunch wheatgrass seeds at $20^{\circ} \mathrm{C}$

\begin{tabular}{|c|c|c|c|c|c|c|c|c|c|c|}
\hline \multirow[b]{2}{*}{ Days } & \multicolumn{5}{|c|}{ Awned trials } & \multicolumn{5}{|c|}{ Deawned trials } \\
\hline & 1 & 2 & 3 & 4 & $\overline{\text { avg. }}$ & 1 & 2 & 3 & 4 & avg. \\
\hline 2 & 0 & 0 & 0 & 0 & 0 & 0 & 10 & 0 & 0 & 2.5 \\
\hline 4 & 15 & 10 & 5 & 10 & 10.0 & 50 & 75 & 15 & 75 & 54.0 \\
\hline 6 & 40 & 40 & 25 & 45 & 37.5 & 70 & 85 & 70 & 80 & 76.0 \\
\hline 8 & 40 & 40 & 30 & 60 & 42.5 & 80 & 85 & 75 & 80 & 80.0 \\
\hline 10 & 40 & 55 & 44 & 65 & 51.0 & 80 & 85 & 75 & 80 & 80.0 \\
\hline 12 & 40 & 55 & 45 & 65 & 51.2 & 80 & 85 & 75 & 80 & 80.0 \\
\hline 14 & 40 & 55 & 45 & 65 & $51.2^{1}$ & 80 & 85 & 75 & 80 & 80.0 \\
\hline
\end{tabular}

${ }^{1}$ Total germination difference were highly significant as determined by paired-sign testing.

Table 3. Influence of awn length on germination percentage and vigor index of "Secar" bluebunch wheatgrass at $20^{\circ} \mathrm{C}$

\begin{tabular}{lcc}
\hline Degree of awn removal & $\begin{array}{c}\text { Percent germination } \\
\text { (14th day) }\end{array}$ & Vigor index $^{\mathbf{2}}$ \\
\hline One-third & $63 b$ & $11.1 a$ \\
One-half & $67 b$ & $12.1 a$ \\
Two-thirds & $62 b$ & $11.9 a$ \\
De-awned & $59 b$ & $10.9 a$ \\
Awned & $54 a$ & $9.8 a$ \\
\hline
\end{tabular}

${ }^{1}$ Means followed by the same letter do not differ significantly from each other at the $5 \%$ of probability using Duncan's multiple range test.

${ }^{2}$ (Vigor Index) $V I=N X / D X$ where:

$N X=$ number of seeds germinated/day

$D X=$ number of days from start of germination to $X$ day (Maguire 1962).

mechanical removal of the awn and insure better establishment on erosive sites. Care would be needed to ensure that seeds do not become mechanically injured during the debearding process. Such an injury could result in a decrease in total germination.

Specific location of an inhibitor or group of inhibitors was not statistically apparent (Table 3 ). Seeds with awns completely intact were consistently lowest in germination. The highest germination percentage was with one-half of the awn removed but was not significantly different from those with other degrees of awn removal. There were no significant differences in Vigor Index. Thus, the partial or complete removal of the awn appears to increase total germination but not speed of germination.

\section{References}

Anonymous. 1979. Recommendation for the release of a variety of bluebunch wheatgrass. USDA Soil Conserv. Serv. Plant Materials Center. Pullman, Washington.

Ellern, J.S., and N.H. Tadmor. 1966. Germination of range plant seeds at fixed temperatures. J. Range Manage. 19: 341-345.

Goebel, C.J. 1978. Grass establishment on lower Snake River rangelands. Proc. First Internat. Rangeland Congr., Denver. $11 \mathrm{pp}$.

Goebel, C.J., M. Tazi and G.A. Harris. 1988. Secar bluebunch wheatgrass as a competitor to medusahead. J. Range Manage. 41: 88-89.

Harris, G.A. and C.J. Goebel. 1976. Factors of plant competition in seeding Pacific Northwest bunchgrass ranges. Coll. Agric., Res. Center. Washington State Univ. Bull. 820. $21 \mathrm{pp}$.

Maguire, J.D. 1962. Speed of germination - aid in selection and evaluation for seedling emergence and vigor. Crop Sci. 2: 176-177. 